convalescent, and there is no doubt that many a convalescent from typhoid is taken to the hop-fields, and their linen, which may not have seen the tub for weeks, is washed in the adjacent stream. Should any of the streams become polluted during the present outbreak at Maidstone by cases removed from that town during convalescence, it might spread the disease into the villages and amongst the rural population. I lave not seen this state of things alluded to in any of the correspondence in the medical or lay press, and I think it is not known what a large number of people are dependent for their water for daily use on the streams and rivers of this county. I hope your discussion will be the means of moving the county sanitary authorities to inquire into the state of the water supply for the rumil population not only of this, but of other districts with little or no well-water."

[For discusirion on this paper, see page 15:].

\title{
CONTAMINATION OF WATER SUPPLIES BY ENCAMPMENTS OF HOP-PICKERS, GIPSIES, ETC.
}

\author{
By Miss CHREIMAN.
}

Read at Sessional Meeting, November 1897.

\section{ABSTRACT.}

Ar the commencement of the Summer vacation of 1895 , I lad occasion to visit Hawkhurst in Kent.

I found there, as elsewhere, an opinion that for the four or five weeks of the hop-picking, the pickers have a delightf ul and must healthful holiday; but, watching with some care, I had no little occasion to cloubt this, and I decided to visit for fuller observation more central districts of the industry.

I did not get far, for I found a perfection of wretchedness that held me close for such poor tinkerings of relief as here and there I could effect; and so, anear and uncovered, I looked upon this so-called holiday, a gangrened wound at the vitals of 
the nation, as different from the pleasant phase of simple country labour and rest that would add to our national virility, as is the freedlom of its perditions from the happy liberties of law and order.

I went alone next year for even poorer tinkerings, and this year I am only putting in train a little plan for some supply of free or cheaply cooked foor for ailing women and children, which I hope may be possible.

This on a large scale, if some one abler would take it up, would be a useful sanitary measure, for wholesome food is a proved preventive of sickness as well as of crime.

Many people go down a week or fortnight before commencement of the picking, afraid of not being in time for engagement, or ordered by hospital dloctor to "get into the country"; and I wish you could all watch just once as the kindly mistress of the coffee tavern at Paddock Wood tries to minister in the dead of the night to these holiday (?) makers, with nothing to spend, and nowhere to go; to crying cliildren and mothers literally too weak to keep their babies in their arms.

The hardest economist amongst you would put his hand in his pocket and make easier the halfpenny cup and slice they pay for, I think. And they do want work. To many this year Mrs. Sladwell, the tarern keeper, made loans of money; all but one found work and repaid her.

We insure ruinous multiplication of our defective population by allowing the production of hundreds and thousands without serviceable hereditary aptitudes, and neglecting to take them off the roads. And one cannot be about the country without seeing how largely this is the case. For instance, I saw an idiot girl of seventeen the mother of two children, and a father and mother with six, tramps all their lives.

Another item of waste that struck me was the very large number of tramps, picked men who lave served the short. military term, trained and disciplined at their country's expense on the road, whilst we are beating the conntry for recruits.

Considering numbers and conditions the amount of order is astonishing, but Vice revels, in the absence of powerlessness of authority to the most afflictive detriment of respectable poverty; and of some out-lying places after the nightly emptying of the public houses and of ten in the neighbourhool of the railway station, though here matters have improved, any enquirer may hear of frightful violence against which the few police are powerless.

"We don't interfere with the hoppers if they don't interfere with other people," say the police, and indeed they are utterly powerless to do so. And so men "fight it out," and women 
too, not seldom with babies in their arms. And they are used to suffering, and punishment recoils upon themselves, and so they can bear most merciless bruising, and when fists and boots have done their worst, unconscious women are dragged to their shelters, or lie by a helgre until they can crawl to them.

I beg to put before you that such gatherings require that habits of obedience to law be established by more effective enforcement of liwful authority.

Would it not be possible to swear in some of the idle army reserve men who are on the unions; or hoppers of good character as special constables?

Dissatisfaction arises through the bringing down by farmers of vastly more hands than required, and there is no power to prevent this; a "catch and hold them" policy of not letting the people know the conditions of work and payment before they start work; the progressive clemands of the "tally," and the grossly unfair practice of measuring which prevails, by which instead of the stated seven or eight bushels for the shilling, nine, ten, or more must be picked or heavy-hancled measurers bribed. It is only of poverty that 25 per cent. more than a bushel can be bought for a bushel. They could not try it with their potatoes, or sell a bushel and two gallons of corn as a bushel. Is it strange that the needy people so provoked are not always exemplary in self-control?

Towards Canterbury, and in Surrey, I am told, three-bushel baskets prevent to a great extent the "measuring injustice." It ought to be prevented.

These people are not all unlovely. I could tell of tender care of infants and love of flowers; of generons giving even to the grift of life; of cleanliness and almost elegance amidst vile surroundings; of a grand British capacity of endurance that ought to be of more service to us.

I could tell of the marvellous benedictions of the air in recovered health; of heroic bearing and noble control under "weiglit of dire amnoy," of some enjoyment, and a little honest laugliter.

But these are not our business this evening.

We want some enforcement of separation of the sleeping places of men and women. Tust one example:-

On the upper floor of one barn $45 \mathrm{ft}$. long, $18 \mathrm{ft}$. wide, with pathway down middle, roof sloping from $2 \mathrm{ft}$. 6 in. to $10 \mathrm{ft}$, forty-seren people were sleeping-men, women, children, yonths, and girls; with no separation other than that a few of them contrived by use of their bed and day clothes.

The family compartments in some barns were comparatively well separated. 
They were divided by hurdles through which straw had been loosely drawn. This, however, could not be said to give privacy, even if the door at one end had not served for the ingress and egress of the ten families.

Some of the dwellings of which the end walls, the divisions, doors, and beds are of straw look so dangerous that one wonders that fires, attended with considerable loss of life, are not of frequent occurrence.

Tents might perhaps be made fireproof-certainly many of them ought to be considerably more waterproof.

We badly want some provision for decent people of places where they can be decently lodged.

Is it altogether impossible for philanthropy to possess itself of a few blocks of model shelters and make use of them for holiday outings all the summer through?

We vant some prevention of the hasty pairing of men and girls to meet the regulation of farmers who employ no single men. Such "matches" are frequent, and much of the subsequent birth worse than infanticide.

We want some prevention of absolutely poisonous overcrowding.

In the casual wards of the unions, with beds overfilled, and corriclors paved with human riff-raff (or the unfortumate in process of conversion into riff-raff) unwashed, clothed in living rags, and packed close as sardines; and in many of the cattlepens, with their manure-mud floors, or the upper compartments of huts receiving impure gases from rooms beneath, the nights of the herded ones must be sleepless, or their sleep of an anesthetic character; it cannot be the sleep of health.

Probably many are only saved from asphyxiation by the impossibility of making these shelters as draught-proof as their paucity of bed-ciothing inclines them to do; and by the benorolent antagonism of carbonic acid to the laws of gravity and coliesion.

Sickness, diarrhœa, spasm, and general malaise are frequent, of course, boils and carbuncles sometimes follow; but these pains and penalties are nature's danger signals and protections; unchecked retention of the morbid poisons would mean painless death.

In the almost unrestricted travelling and distribution of these people in conditions of incubation, is it not certain that we have explanation of not a little of the prominent mortality and the prevalence of non-fatal, foul air and water-borne disease, common to October and November, so that much of the suffering and death,--as well as birth and vice-accredited to London is due to the hop and fruit harvests.

And is not this in some way the business of London?

VOL. IIX. PART I. 
Disinfection of the hop-pickers' trains should be thorougl and regular.

At the end of one harrest attention was called to a case of diphtheria on a cattle fold. The patient was detained, the other lorlgers of the foll returned lome next morning. These people had been lying upon a bed of short straw, beneath which was a mattress of cattle manure two spades deep. Could fever desire a better loot-bed, or better chance of diffusion?

A fortnight after the picking of 1895, I went down with $\mathrm{Mr}$. Coyle, a London Arehitect, who had very kindly undertaken t." give me some suggestions for better housing.

It struck botl of us that the disinfection of the shelter's, the cleansing or earth corering of the latrines (where these exist), and some attention to their excrement-sodden approaches and the removal of the leavings of the hop pickers, might be wise, and at an early date after completion of the picking.

In many cases the hoppers are hurried from the fields, with what looki like indecent liaste, tents being pulled down whilst they are being paid off-they wash and shave and change their clothes in the roads. It seems to be no one's immediate business to remore these clothes, numbers of old boots and stockings lie about. One red jacket rester close to the top of the well-used steps between the Station and Maidstone Road, for three weeks.

Wells, I am told, go for twenty perhaps fifty years without cleansing. I heard of one well that was not disused until the dead frogs and snails and newts had so "tumbled to pieces" that. the stench of the bucketfuls drawn was mbearable-and of another disused for years because its water was black, that just by means of a big bunch of holly and furze-bramble weighed with bricks became the enry of the neighbourhood for beauty of flavour and appearance.

I leard of one farmer having water boiled and sent round for use of the pickers, and most cmployers would provide water, but good water is a great luxury in several places in Kent. At least one property owner in Paddock Wood is between the horns of a dilemma. He has been served with notices to discontinue the use of well-water under a penalty of $\mathfrak{E 2 0}$, and his tenants will not use the supply of the water-worls company.

People at Paddock Wood reasonably ask why they should pay for water that may poison them if they drink it, and spril their clothes if they wash them in it.

It does seem that privilege of possession and supply ought to cover reasonable certainty of protection, cleansing of dams and courses, and preparation for use; and that the "taking good dividends, and taking away our friends and bread winners who pay them," as one householder put it, ought to be prevented. 
A little enterprise and expense would make an excellent supply available at Paddock Wood.

A splendid spring exists close at hand with completest natural advantages for rescrvoir and conveyance.

Provision of some kind is necessary, to prevent the bathing of swollen legs and sore feet, the washing of shirts and pants and stockings, and worse defilements of water, afterwards "caught" for drinking and cooking. This goes on in various places during the hopping-and all the year round in "wash up skippers"-or pieces of accessible water courses sheltered by trees and a hedge where impecunious travellers wash, cook, spend a night or nights, and so "slip" the Union. It is not pleasaut to sce watercress from these beds "enjoved."

Rough temporary laundries might be possible. A doctor who had a practice in Notting Hill, told me that a good many laundry girls out of work during the London holiclay season go down for the picking, and, added the doctor, considerable increase of practice always follows their return.

It seems to be probable that infection is sometimes conreyed to cattle and poultry by contaminated water and regetation.

In fact we have on every hand a superabundance of the best food for the growth and development of malarial influences; cycles of infection need manifold calls for cleansing, ventilation, and some provision or substitute for drainage to prevent air and witer fouling by noxious products of decomposition, with extensive evaporating surface.

I visited before, cluring, and after the hop-harrest a field, on which during the harvest were 170 tents-" housing" each from three to fifteen men, women, and children. On this field I was informed that there was not a single sanitary convenience. On another farm was one for the use of some linudrecls of people-absolutely unapproachable, and (if I remember rightly) apparently draining into a pond, from which it is to be hoped that water was not drawn. Most of these people fetched water from a somewhat less stagnant pond farther off.

Foods absorb the poisonous effluvia of the sleeping-places, and-stale at time of purchase-are soon in a state of putrefaction.

A food case might be a possible addition to improved dwellings. I kept milk for a few sick people sunk in the earth in tin pails.

We want local inspectors aided, for better orersight of supplies of food. I sometimes saw meat hideously evidencing its need of condemuation.

I heard that bacon that needed chaining was being "doctored" (will members of the Profession of Medicine kindly 
excuse the term) for sale in a shed; and knowing that one historic pig had been credited with the infection of 158 persons, and sceing raw bacon eaten, I could not but think that the aches and pains of some of these people as likely to be from Trichiniasis as from suppressed gout.

Some of the hop-pickers' beer is abominable stuff, and I remember hearing either Dr. Taffe or Dr. Carpenter state that bad beer was almost as likely as milk to be a medium of infection.

I heard grevious complaint of tinned meat the half-clay I spent at East Farleigh this year.

Please unclerstand that $I$ am not gainsaying much painstaking provision, by local tradesmen, of food of astonishing quality, considering its price.

I realized (very sadly sometimes) the difficulties the people find in getting supplied. This is more especially the case with milk-often greatly needed for infants and the sick.

We want, knowledge of disease at its onset; and $I$ do not see how compulsory notification is obtainable unless assistant inspectors mix with the people at the bins and elsewhere and get it by observation of premonitory symptons. Suspected cases might then be removed to hospital tents.

The late Sir Edwin Chadwick once told me that during a cholera epidemic he borrowed military tents from the Tower for a somewhat similar purposes.

Such hospitals even if only for first aid to the injured, would I should think, be great help to the local doctors and a boon to many sufferers-and cases of pneumonia, bronchitis, feverish rheumatic conditions, rapid decline of consumptive infants and children brought down for "their health" are far from infrequent, and conditions for nursing, dying (even burial, thougtthis matters less) are very different from what should be desired.

I was frequently struck by the determination to "get back to London" directly illness manifested itself, or at any rate so soon as it became serions, and the danger of this is obvious.

And some painful cases of suffering from delay of conveyance of injured persons to hospitals several miles distant, came under my notice.

I wonder if there is any way of destroying the odour of the egg and fish mantures, so largely used on the fruit and hop. grounds?

I am told that fish manure is laid a foot deep over some of the hop fields, and that when the decayed fish is brought in during October, and its trucks stand at the station, and waggons full or emptied pass along the road, the stench is unendurable.

How men accomplish the loading and unloading is a mystery. 
Hundreds of gulls are attracted by this fish: " eight," said one of my landladies, "fell dead in our garclen last year, nasty stinling things, my husband threw them into a ditch at the bottom of the garden." This was of Elm Tree.

I camnot believe that any smell can be worse than that of egg manure, and a deposit of thousands of rotten eggs and their straw which I saw within a few yards of some hopper's' huts made the sense of smell torture for weeks, as, owing to the greatness of the mass, reduction of temperature to point of cessation of offensiveness was very slow.

It ought at least to have been lightly covered with earth to lessen the evaporating surface, and so minimise the giving off of morbid particles likely to give erysipelas, or carbuncle, or diphtheria to the individuals in proximity to it.

Surely much improvement is possible in respect of the conveyance of the pickers.

In respect of fares, pleasure parties are carried in far better carriages, at convenient hours, without tedious delays, \&c., and at, I believe, greater reduction of fares.

To Paddock Wood, ordinary third class fare is 2 s. $11 \frac{1}{2} \mathrm{ll}$. By the "cheap" hoppers' train, 2 s. Would it not be possible to arrange for the arrival of the night trains at a time, 5 or 6 a.m., when people can get to their places of work, instead of lying about the roads and platforms for hours with most of the waiting rooms locked, and arrangements for comfort utterly insufficient, or absolutely wanting? To give the people the status of fourth class passengers with fixed starting times, \&c., instead of beasts of burden and other chattels, started when the trains are sufficiently over-loaded.

The night journeys have been improved, but are not free from debasing and demoralising neglects, and it behoves the railway companies, and our Christian Government, if beyond the power of the railway companies, to make our railway system of better service to those whose low degree of civilization is a public danger, and to whose personal and collective malinfluences all public contact ought to effectively oppose educative contrast, and evoke wholesome self-control.

Some of the people drive down from London, and I never once knew any remonstrance or attempt to prevent over-loading, over-driving, flogging or starving of the worn and jaded beasts. There seemed to be no knowledge that dumb creatures possess sense of pain.

It is legal and usual to open public-houses for three-quarters of an hour after the arrival of the night trains. Would it not tend greatly to the comfort of the women and children, and to the lessening of frictions, noise and delay, if these houses were 
permitted to open not for the sale of "hoppers' beer" and spirits, but on condition of supplying cheap brealfasts of coffee and bread and butter, with if possible mill for infants and weakly cliildren?

Might not the workhouse better serve the community, better conform to the spirit of the law, by making provision for better lodging (old reserve military tents might be available for this perhaps), and for some service of soap and water without punitive rletention whilst so many penniless wayfarers are anxiously seeking work, whilst it is necessary easily to obtain labourers, and whilst Church and State need for their slumdwellers the outings of which they may yet learn the beneficent possibilities.

I acknowledge the difficulty of the problem, but national questions ought to be righteously faced, and, as (let us hope) a large majority of the prople are not rogues, it hardly secms ethically sound for the workhouse to usurp the function of the prison, and punish by excess of engagement-prohibiting detention.

Nor to me-except on the principle that "from him that hath not shall be taken even that he hath "-does it seem quite the thing to exact for such honsing as previously mentioned, and one $\mathrm{Ib}$. of bread, with "nothing further" (as in very large type the notice outside Penbury Workhouse puts it) the breaking. of not less than ten cwt. of stone on four successive days', even for a second application for admission within the hopping month, whilst applicants are liable to seven or fouteen days hard labour for sleeping out. Ought not better management to provide soap and towels and a little courtesy, and still leave some change due to the impecunious lodgers?

I met at Penbury, an exhausted footsore family dismayed on finding they had if further six miles to walk to get and "return with an order of admittance to the workhouse for the night.

Might not this great and useless hardship be removed and the admittances issued from an office adjoining the worklouses? The only apparent advantage of the usual plan is the possible recognition occasionally of some one "wanted" and for all the unwanterl to pay for this in soul destroying weariness can hardly be ethically sound.

The workhouse that serves Mitidstone is, I am told, at Coxheath, about fire miles distant.

With regard to the great question of cost of reforms we have, among other things, to consider that our requirements are being made in days of greatly lessened values of the produce of the harvests by foreign competition and protection, and we have to consider the difficulties of provision for great numbers for a very limited period yearly. 
The entire community, notably London, would share the advantages, and it seems to me that a policy of voluntary assistance, as well as official compunction, might be a paying policy-I think the hand of benevolence might do well to facilitate improvement and lighten the burden of municipal pressure, in the interest of those, by whom and for whom, the outing is so much needed, and of the employers whose shrinking profits and growing responsibilities already tend to its curtailment.

The matter wants looking at all round, and I think you would do well to take two or three of the leading growers into rour council. I heard constantly of the fairness and kindly vigilance of Mr. White, of Bellering, near Padrlock Wood, who, I have been told, emplurs two to three thousand pickers. His arrangements include zinc houses, cooking places and lattrines, pumps, a fire engine, medical advice, a printerl list of regulations, a weighing of hops, saicl to be nowhere else in use-which prevents gross unfaimess of measurement-and some care for the departure of the pickers. I don't know Mr. White-he may be here, for he was invited, I believe-I think his co-operation would be of service.

I have been asked if I observed the work of the Church. Sirs, I observed it enough to say thit your greatest sanitary measure would be the conversion of the majority of churchmen to the truths that a few of their number are always so splendidly illustrating, and talismanic touches of divine ointment were so obviously ineficient that much I wished that those who send a handful of missionaries and scripture readers (with free hearts and tied hands) into the teeth of the tempest-to tell the strugghlers therein that perhaps they may be buffetted by earthly winds and wares right into a heavenly harbour of peace-could realize the cumulative and concentrated force of the secular, in lives in which the secular (a pitifully limited region of it.) holds all the facts.

These men were charged to take Christ to the people, and they made their presentation with an ingenuity and readiness of application of His attributes and teachings (in gentle sympathy and stern reproof) that rarely failed, and seemed to me altogether admirable.

It was hard for them to find their "all satisfying spiritual facts" confronted and opposed by the supreme verities of liunger and dirt and hopelessness.

What an epoch-making quickening of heart and conscience we should have; what alssorption of factional and indivichal into judicions national effort and expenditure might follow, if you could induce the church to estimate its responsibilities as 
if its God understood mundane mathematics, and would follow carly audit of effort and achievement by proportioned condemmation or award.

I wonder if, then, their churches and chapels would be closed all the week to these homeless and harrassed ones.

I think that not only for prayer and praise, but for decent feeding (perhaps cleansing); and for the great miracle of opening their eyes to their condition and requirements, their duty to the State and neighbours they distract, and the children and animals they torture, these doors would be opened wide. This would be so much saner than requiring our wastrels to sing

"Goodness and mercy all my days Have surely followed me,"

and fancying that in some hidden way Providence is cloing our work.

Even if for part cost of the new departure the church kept some thousands of pounds of its missionary money on this side of the ocean for a while, and so spared its members the giving up of their competitive extravagances of entertaining and adomment. CORFIELd.]

The Chairman (Sir Douglas Galton) read a letter he had received from the Chairman of the Sanitary Committee of Maidstone which ran as follows: "I very wuch regret that I cannot attend on Wednesday next, for, as you may suppose, the questions to be discussed are particularly interesting to me as Chairman of the Sanitary Committee. I may say that I cannot entirely agree with the statements made by the correspondent of The Times as forming a correct judgment of the question of the housing of the hop-pickers. We must bear in mind who they are and whence they come."

$\mathrm{He}$ also read the following extract from a letter received from Dr. Adaws, the Medical Officer of Health and Analyst of Maidstone: "I am very sorry to have to decline to take part in the conference on the pollution of water-supplies. I would willingly do this but my time is so taken up with the duties of my office at the present time that I should not be able to do justice either to the Institute or to myself."

Dr. G. H. Fosbroke (Worcester) said when he received au invitation to attend and make a few remarks on the pollution of water supplies by hop-pickers, \&c., be accepted that invitation with 
much pleasure, as the discharge of the duties of his office in Worcestershire had brought bim much in contact with hop-pickers. Sir Douglas, as (hairman of the Sanitary Committee of the County Council-and he boped that Sir Douglas would long be spared to them to adorn that office-instructed him to enquire into the conditions under which the business of hop-picking was carried on, and he conducted the enquiry towards the end of the season of 1895 . There are in the county eight rural districts in which hop-growing is carried on, and in one of these districts he found fifty-seven hop gardens; and although some were not many acres in extent, other's extended to several hundreds of acres. Hopping usually commenced in August and lasted until the beginning of September. Of course it is necessary for the harvest to be gathered very quickly, and that being so the local labourers are totally inadequate for the work, and large numbers of hop-pickers drawn from the "Black Country" are imported to assist, the majority being people of the lowest class. It was found necessary to maintain a number of police to keep them in order, and eventually the farmers tried to improve on the class of labourers to be imported. Now farmers go down beforehand to the "Black Country," and find some old dame who will undertake to engage hop-pickers on commission, and generally women are engaged. It is found that women do more work than men, are more industrious and certainly more orderly. Too many of the farmers have no house in which to lodge these people, and the result is that many have to be put in draughty cattle sheds and bains foul and damp, out of which the farmers had turned their cattle. But these conditions did not everywhere previlil throughout Worcestershire. Some gentlemen thought this state of things would not do, and tried to make better provision. Some of the leading agriculturalists supplied their casual labourers with food and bedding. The result of such an undesirable state of things was that some contracted pneumonia, others scarlet and typhoid fevers, or diphtheria. They laid on heaps of straw, and did not call in medical aid until extremely ill, and then they would send for the parish doctor. After the hop-picking season is over we get outbreals of scarlet fever, which are evidently due to importation of the disease. He was instructed by the County Council to draft a set of regulations, and these were put in force in several districts, but other district Councils did nothing. This could be done quite well under Section 314 of the Public Health Act of 1875. These regulations were similar to some of those in force in Kent, and require huts to be waterproof, to be limewashed annually before using, to be generally sanitary, and to be provided with fireplaces, one for erery trenty persons. The picture of the state of the pea-pickers is still worse. A farmer who grows peas one year will not grow them the next year, and as he has only casual harvests which only last a fortnight, does not feel justified in going to the expense of erecting shelters for the pickers, and generally no provision at all is made. The pea-pickers are generally tramps and those of the worst class. Some find bundles of pea-straw, known as pea-haulm, to lie 
upon, and many have no shelter. Some sixteen or seventeen years ago be was called upon to investigate in the town of Evesham an outbreak of typhoid. A few days after the regatta he was informed of a large number of cases that had broken out in all parts of the town. He found that these people had consumed lemonade made from the water of a certain well near which was a camp of van occupants and gipsies who sold so-called ice cream and lemonade which were only iced water. All the evidence pointed to the probability that the outbreak was due to the pollution of this well through the filthy habits of the occupants of the gipsy camp. He feared that many other sources of water supply were not what they ouglit to be, although, through the influence of district councils, a better state of things now prevails. By enforcing these regulations for hop-pickers many of the evils conld be removed. The powers given under the section are permissive only and not compulsory. There is a ma!y still existing, but I hope the time will soon come when may will become stutl.

D1. J. S. Trw (MI. O. H. for West Kent) said, we bad heard from Miss Chreiman a good deal about the hop-pickers, and of the way in which finmers treat them. He was quite aware of the sbortcomings of some authorities in regard to the water supply and the bad state of the hop-pickers, but if the sensational statements made were left unchallenged many wonld go away with a wrong impression of the way in which hop-pickers are housed in the County of Kent. We have also heard from Dr. Fosbrooke of the state of matters in Wolcestershire, and of the low type of persons who are employed there, but he was afraid those coming into Kent were drawn from a still worse source. We get every lind and sort, but to assert that nothing is done to benefit them is quite wrong. With regard to the model by-laws framed under Section 314 of the Public Health Act, some which apply to urban districts may not apply to rural clistricts, but suitable by-laws lave long been in force in the rural districts of Bromley, Crambrook, Maidstone, Tenterden, Sevenoalis, Tunbridge, West Ashford, Dartford, and Bexley, and other districts in Kent, and at the beginning of every season a notice is sent to hop-grower's calling attention to these by-laws which he linew to be regularly enforced in most of those districts. He hitd before him the Thirtieth Annual Report of a society formed for the better carriage and the improvement of the hop-pickers. It has certain rules by which the hop-pickers can be benefited while in the hop tields. It provides for notice to be sent to the hop-pickers likely to come, of the accommodation and the size of the hopper-houses at the different points. This socirty appears to be not much known, but it does good work and is conducted principally by hop-growcrs. Special requests are made to prevent from being sent, persons who are ill or who cannot work. People who come down beforehand are the cause of much apprehension, but many of them are tranjs, gipsies, and habitıal loafers not seeking bonci fide work. All cases of zymotic disease are 
at once removed for isolation, in some districts to permanent hospitals, and in others to temporiary hospitals. He must cortainly take exception to the statements made that the hop-pickers are totally incared for.

Dr. Percr Adars (Deputy M. O. H., Maidstone) said : He was there partly to defend perhaps, and partly to hear what Dr. Corfield had to say about the pollution of water-supplies. He had observed some weeks betore the outbreak at Maidstone, the appearance of diarrhoea as a precursor of the severe typhoid epidemic which followed. This was woen he first had to make an investigation, and at that time the whole enquiry devolved on him. He was much struck with these premonitary cases, and he reported to the Sanitary Conlmittee nineteen deaths from diarrhoca. The Committee then had before them but four cases of enteric fever. He found in certain localities large areas affected by diarrhas, the indications being most marked in a certain section of the water-supply. In one section of the water-supply, which was regarded as the most suspicious they had bad, a marked increase in the number of cases of diarhoea before interic fever broke out in Maidstone in an epidemic form. 'The point he wished to emphasize wis this: Is it not worth while to draw attention to the relation, if any exists, between diarrho'a, and such allied diseases, which we may call colitis, \&c., and well-marled enteric fever? If we were to apply the theory of evolution to these facts, should we not find them more closely related than has hitherto been supposed? He thought with Dr. 'lew (who had even had a greater experience than himself, because he was a M. O. H. in the centre of the hop district) that "The T'imes" is a little too hard on us. Many of us in Kent have been brought up in great familiarity with the customs of these hop-pickers, and long immunity from serious outbreaks of disease may hare dulled our apprehension of them. Sanitary science has made rapid progress, and our famers have perhaps not picked up the threads too quickly, but lie did not think the fault lay so much with the firmers as it did with owners. The letter in "The Times" from Mr. Hardy, Chilham Castle, shows how important these local interests are, and that there ale honoumble men in Fient who would do a great deal more for their pickers if they only knew how? 'This discussion will perhaps indicate what is being done in other counties. As regueds the provision of latrines, the hop-pickers during the greater portion of the day are scattered over the fields far away from any places in which proper latrines can be provided. From a bacteriolugical point of view, as well as from the point of view of the Sanitarian, it would be intinitely worse to have improperly constructed latrines than if deficcation were made in the open air, and it would be impossible to provide proper latrines in the places where these people pass the greatest part of the day. We have perhaps been accustomed to think that these pcople come down every jear and enjoy a fair amount of health, and perhaps farmers have come to think that as the hop-pickers have lived so many years without having 
good shelters provided, they might continue to live without such. He thought farmers now saw that they were in error and that more provision ought to be made. There were undoubtedly cases calling for such reform, but there were also cases where food, water, and good shelter are provided, and where the hop-pickers are cared for as well as circumstances will permit. Altogether he was of the opinion that these insanitary conditions around Maidstone are very much overstated.

Dr. T. C. Throsin (M.O.H., Essex County Council), said it was diffucult in l'ollowing so many dillerent speakers to avoid going over some of the same ground, liut the great importance of the subject justified some reiteration. The necessity of protecting our water supply hiss been discussed for many years by eminent sauitarians, and too often apparently they have preached to deaf ears, but now the public was more willing to listen to advice. The alarming epidemics of typhoid fever at Maidstone and elsewhere have aroused public attention and emphasised the danger of neglecting the protection of our water supplies, and in future we may have reason to icknowledge the present calimities as blessings in disguise. $\mathrm{He}$ had bad occasion to examine very many sources of water supply in this and otber counties-supplies both for small and large communitios-and in far too many cases he had found an almost utter want of care in protecting those sources. He had felt in some cases inclined to regard the carelessuess and negligence as almost criminal, having regard to the unsuspecting and ignorant consumers. Besides the pollution due to hop-pickers, tramps, and gipsies, there are many causes from which pollution may arise. Wells and other sources of supply are often contaminated by the proximity of foul streams, badly constructed sewers, or public conveniences, but the contanination caused by encampments of van people, harvestmen, tramps, and the classes of whom we have recently heard so much in Fint, is undoubtedly one of the most dangerous forms of pollution. Fresh human excrement he had always regarded as more dingerous than any other kind of manure. Manure diluted with less objectionable matters, which has generally undergone clianges which have resulted in the destruction of a large proportion of the organisms so inimical to the human race. Hop-pickers are limited to a few counties, but all counties are liable at certain periods to incursions from certain nomadic people. He was engaged in a county where, in the summer and autumn, a great many people are temporarily employed, and for whom accommodation is not always provided by the employers. and so long as it is not provided we must run the risk of our wells and streans being polluted from this cause. His experience led him to admit that the maling of by-laws for regulating the sanitary conditions of such encampments has been much neglected, and that in many districts where by-laws have been framed, the difficulties of enforcing them have seemed almost insurmountaljle. More could be done than bas yet been attempted. The prorision of latrines and of easily accessible supplies of water should be always enforced. It is 
true, as we bave recently found urged in Kent that the sanitary authorities may compel latrines to be prorided, but they cannot compel the people to use them, still if one portion of the population cannot be got to do its duty that is no excuse for another not doing it. Whether sanitary conveniences are provided or not, every possible precaution should be taken to prevent people of these classes from having access to the source of a public water supply. There should be "protective areas" around all sources of supply, every spring or well used for domestic purposes being properly safe-guarded. Hitherto water companies and sanitary authorities have been allowed merely to acquire springs and sites for wells, but they should be compelled to acquire sufficient of the land around in order to obtain such a control as rould effectively prevent pollution. My friend, Mr. Whitaker, also suggests a "protected area," but he uses the term in a different sense. My sense is that the acquisition of such "protective areas" should be made binding on all water authorities, and, in the future probably, this will always be insisted on. We should follow the example of Glasgow, and obtain control of the whole water shed. The conditions of different sites vary so much that no general rule can be adopted. In cletermining a site many factors will have to be taken into account, the deptl and nature of the sub-soil, the height of the ground water, and the fluctuations due to season and to pumping. Had there been a reasonable protective area around the springs at Tutsbam, almost certivinly the Maidstone epidemic would not have occurred. The Maidstone and Lynn ontbreaks will serve to direct increased attention to the immense stores of undermround water, in strata naturally protected from pollution by thick impervious layers of clay, but water, eren from such a source, may become contaminated, unless proper precautions are taken. County Councils could do much, he thought, to protect the population. He had within the last few days presented a report on the protection of water supplies to his County Conncil and had asked them to consider whether they could not do something towards safe-guarding the public. No sanitary authority or water company with satislactory sources of supply would reasonaljly object to their being examined periodically by a competent person. Neither would any authority or water company really anxious to saferuard their supplies object to such inspection. The examination of the sources of water is much more important than any analysis. He did not mean to say that analyses of water were unnecessary, for occasions do occur when an analysis will reveal pollution which had previously been unsuspected. His recommendation was the prorision of a protective area round every source of water supply, inspection at regular intervals say once a year, and analyses every quarter or every month or even oftener according to the importance of the supply. Experience has taught us the necessity of striking while the iron is hot and he congratulated the Sanitary Institute upon the opportunity it had afforded them of discussing that important subject at so opportune a moment.

Dr. Cimandis Ponter (M. O. H., Stockport), said: At the Congress 
at Newenstle in 1896 he had the honour of submitting a paper which contained suggestions for amended legislation on this subject. $\mathrm{He}$ embraced with pleasure the opportunity aftorded by this discussion and the present bealthy state of public opinion in regard to watcrsupply to bring again to the notice of the Institute what harl been aptly christened by Mr. limest Hart "The autocracy of private water companies." He wished again to call attention to the unjust and anomalous condition of the law which, whilst it provides for the inspection of the premises and the goods of food vendors generally, leaves sanitary authorities (ontside the Metropolis) without any similar powers of protection of their water-supplies, when in the hands of private companies. The sympatiny and intuence of the lnstitute would, he hoped, be enlisted in support of the endeavour to rectify this condition of affairs. An example of the existing disgraceful state of things was revealed by Dr. Bruce Low's recent report on the water supply of Horsforth, near Leeds, where water drained from lind manured with night, soil had been surreptitiously turned into the public mains by a water company, whose high handed conduct had culminated in the statement that they would not allow the sanitary authorities to interfere with the affairs of the company. He thought the time bad come for further legislative action in this mattel: He was here at the request of the sanitary authority he served to state that in Stockport they possessed no right of entry on the waterworks, an! in the past he had been denied permission to take samples from the filter wells of individual filters and had bren refused information as to the bacteriological investigations made by the company of their effluents. The sanitary committee had therefore recommended their Council to petition the Local Government Board to take the necessary legrislative measures whereby every sanitary autbority, supplied by a water company which is not also a sanitary authority, be empowered to authorise any cluly appointed official to enter. inspect, inquire, and take samples at any part of any source or works of water-supply or water puritication at any time, by day or night. and whereby also such water company be required to alford all reasonable facilities and information for such inspection, inquiry, and simpling. He boped the Iustitute would accord its powerful support to this much needed reform.

The Rev. Embrrton Thomas (Vicar of West Farleigh) said Misw Chreiman's paper bears every mark of imperfect observation. No doubt there is in the arrangements made by the farmers of Kent a great wint of sanitation, a want of pure water, and he thought Di. Adlams put this down to the riglit cause. There was no doubt the farmers of Kent had got into a sort of sleepy state and had an idea that this sort of thing might go on without bad results, but when we consider the masters' side we tind there is wuch to excuse them. 'The hop-picking continues only some few weeks in the year and it is very difficult to provide in a proper way for those who are employed only for these three weeks. To fairly conduct an enquiry such as that 
undertaken by Miss Chreiman requires the greatest consideration. He would point out one or two instances in which Miss Chreiman's paper was wrong. The statement was made that the hop-pickers came down to the ficlds wecks before the time. Besides the people who come for the lopp-picling there are the ran-people and tramps. Certainly the tramps who are going ahout the country all the gear round come rlown before the hop-picking actually begins, but not the hop-picliers. They do not go before they arr sent for by the farmers. When the hops are ready to be picked they send to Jondon for the pickers and they commence picking next day. Then it was said the hop-pickers do not know what they are going to get for their work. It may be true of some parts of Kent but taking the county as a whole it is not true to say that they do not know what they are going to earn. The prices paid way vary within certain limits, according to the state of the labour warket and from other causes, but they are usually told before they come down how many bushels they are to pick for a shilling. With regard to the Church of England Society it is not true to charge it with neglect of its opportunities. We have our mouths shut with regard to matters of sanitation. If we were to bring complaints on all these matters of order and management we should not be allowed to enter the hop-fields. We have our school rooms open every night where the hop-pickers play or otherwise enjoy themselves, and many farmers provide recreation for them at their own expense. He liked fair play, but it was not fair to take individual calses of an extreme chancicter as representing the whole. By taking individual cases you cannot find out the true state of aftilirs. Much bad been done towards putting matters right, and he trusted that by the letters in The Times and this discussion, that sanitation among the hop-pickers and the housing of these poor people would soon be improved.

Major Lamonock Fuowsin (Sanitary Engineer to the Lee Conserrancy Board): Much had been said during the discussion, he remarked, that he should have said. He linew he should hiwe agreed with Dr. Fosbroke, and he would have said we must have compulsory unt permissive legislation. In the district administered by the Board of Conservancy of the River Lee there were no hop-pickers, but they had peripatetic caterers for the amusement of the people who give locil authorities a good deal of trouble wherever they come. The foremost necessity for all encampunents temporarily occipied is a proper water supply, and there should be provided proper latrines, whicb, when the necessity for their existence has passed away, can be removed or filled in and covered over, and the ground left as before the occupation. He had risen because a reference had been wade to the River Lee. He did not think they had there more typhoid than in in any other part near London, and he could bear testimony to the care taken by the sanitary authorities of his district to avoid pollution of the water. 
Miss Cnrmimar (London) in reply to the discussion maintained the statement that the people went down fiom one to two weeks beforehand, and they do go down in large numbers much before the commencement of the hop-picking. The practice of measuring complained of was not " universal," but very general, and a constant item of bitter complaint by the pickers, and of regret by observing residents. In respect of the admirable by-laws, a copy of which lad been handed up, she would like to be supplied with the addresses of any farms on which they are carried out. Her observations, though somewhit local, had been over an area serred by some four thousand hop-pickers, in which such regulations most certainly did not prevail. Unquestionably, the pickers were a most difficult people to do with, or for. and assistance and support were required by those who bad to do with them. Unfortunately, in order to sare the time of the meeting, she had been obliged to omit the portions of her paper treating of the care of the missionaries and some of the farmers (notably Mr. White, of Paddock Wood) for the hop-pickers. The fact mentioned by Mr. Thomas that church workers did not complain of unsatisfactory arrangements, to avoid giving offence, was too true, their position was especially difficult. The whole circumstances of the barbarian " holiday" cilled most urgently for philanthropic and official remedy, and anyone thinking of such plea for roform as mere womanish sentimentality had her sincerest pity.

Sim Dovglas Galion, in elosing the discussion, said he had bad a great deal to do with reports on the sanitation of India, and there were wany complaints of water pullution much in the same way as by these people in Fient. No pictures from India could be nore striking than these, which The T'imes and Miss Chreiman have described in Kent. In Australia, where they import a great many coolics, the importers are compelled to provide for their sanitation and care whilst employed, and for their re-shipment; and why not apply the same principle to the people in Kent. who derive so much profit from the hop-pickers? 